Late Holocene anthropogenic and climatic influences on the regional vegetation of Mexico's Cuenca Oriental

Authors: Tripti Bhattacharya ${ }^{a}$ 1, Roger Byrne $^{a}$

${ }^{a}$ Department of Geography, University of California Berkeley, Berkeley CA, 94720

1. Corresponding author: email: tripti@ berkeley.edu; phone: 510-642-3903, fax:

510-642-3370

(C) 2015. This manuscript version is made available under the Elsevier user license http://www.elsevier.com/open-access/userlicense/1.0/ 


\title{
Late Holocene anthropogenic and climatic influences on the regional vegetation of Mexico's Cuenca Oriental
}

\author{
Abstract \\ Scholars continue to debate the relative magnitude of pre- and post-Conquest \\ anthropogenic landscape transformation in many regions of Mesoamerica. These debates \\ have important implications for our understanding of the role of anthropogenic practices \\ in the development, or at times degradation, of regional environments. Paleoecological \\ records that provide long-term perspectives on climate change and human land-use \\ patterns are critical to addressing these uncertainties. However, many regions of Mexico \\ including the Cuenca Oriental, a semi-arid basin in the rain shadow of the Sierra Madre \\ Oriental, remain poorly studied. We present a new paleoecological record from sediment \\ cores recovered from Lake Aljojuca, located in the southern part of the basin. Stable \\ isotope analyses of authigenic carbonates provide an independent record of past climate, \\ while pollen and microscopic charcoal provide insights into past vegetation and fire \\ history. The Aljojuca record is one of the only well-dated multi-proxy paleolimnological \\ records from the Cuenca Oriental, and is one of few charcoal studies from highland \\ Mexico. Zea mays pollen and increased fire activity at 2,700 calendar years before \\ present (cal yr BP) suggest Formative period human settlement around the lake. Between \\ 1,700 and 800 cal yr BP, a drying climate combined with human uses of fire likely \\ resulted in increases in the extent of xeric scrub vegetation. The Aljojuca record also \\ documents important landscape changes during the historic period ( 430 cal yr BP - \\ present) likely related to the introduction of invasive species and agricultural \\ intensification. The Aljojuca record provides a unique perspective on human-
}


environment relationships and highlights differences between landscape transformations in the pre- and post-Conquest periods.

\section{Introduction}

Researchers have long debated the magnitude of human landscape transformation in the Americas prior to European arrival. This debate has important implications for our understanding of the evolution of environments in the Neotropics, modern landscape management practices, and historic carbon cycle dynamics (Butzer and Butzer, 1997; Lentz, 2000; Dull et al., 2010). Studies from lowland tropical regions of Mesoamerica have made strides in providing evidence of past human landscape management (Goman et al., 2010; Wahl et al., 2013; Walsh et al., 2014). In highland Mexico, paleoecological research has also clarified patterns of past human settlement in the western highlands and the Basin of Mexico (Arnauld et al., 1997; Almeida-Lenero et al., 2005; Metcalfe and Davies, 2007; Metcalfe et al., 2007; Figueroa-Rangel et al., 2008; Figueroa-Rangel et al., 2010; Metcalfe et al., 2010; Park et al., 2010; Vasquez et al., 2010). However, significant uncertainties still exist about the nature of anthropogenic landscape transformation in many regions of highland Mexico.

One important area of debate focuses on the environmental impact of preColumbian versus historic land use. Evidence from the central highlands of Mexico shows pulses of erosion in response to both pre- and post-Conquest period land-use (Heine et al., 2003; Davies et al., 2004). Some researchers argue that the historic period resulted in unprecedented landscape change and degradation (Simpson, 1952; Fernandez, 1985; O’Hara et al., 1993; Fisher, 2005; Elliott et al., 2010), while others suggest much more modest landscape changes following Spanish Conquest (Butzer and Butzer, 1997). 
Historic period landscape changes may have largely resulted from post-Conquest demographic changes and the abandonment of traditional pre-Conquest agricultural systems (Butzer and Butzer, 1995; McClung de Tapia, 2000). Resolving these debates requires detailed knowledge of the chronology and magnitude of both pre- and postConquest land use.

The eastern sector of highland Mexico offers a particularly important setting in which to address questions about the character of long-term anthropogenic landscape transformation. While some geomorphological and paleolimnological research has shed light on vegetation and erosion in this area, few of these records are precisely dated (Straka and Ohngemach, 1989; Caballero et al., 2003; Heine et al., 2003). The area known as the Cuenca Oriental is located in the rain shadow of the Sierra Madre Oriental (Gasca-Duran, 1981)(Figure 1). This dry, semi-arid zone is marginal for corn agriculture even today, and drought often results in agricultural losses (Liverman, 1990; Heisey and Edmeades, 1999). Archaeological surveys, however, have revealed villages and large cities that suggest dense pre-Columbian settlement (García-Cook, 1976; García-Cook and Merino Carrion, 1998).

In order to better understand late Holocene environmental change in the Cuenca Oriental, we developed a paleolimnological record from Aljojuca, a volcanic explosion crater, or maar, lake located $20 \mathrm{~km}$ west of the volcano Orizaba (Gasca-Duran, 1981) (Figure 1). Our study represents the first sub-centennially resolved record from the Cuenca Oriental, and uses a multi-proxy approach to reconstruct the environments of the last 4,000 years. This approach is especially valuable because it helps distinguish between climate-induced and human-induced landscape changes, which are often 
difficult to disentangle (Metcalfe and Davies, 2007). Proxies used in paleolimnological research can be influenced both by climate and anthropogenic factors (Conserva and Byrne, 2002; Figueroa-Rangel et al., 2008; Figueroa-Rangel et al., 2010; Park et al., 2010). For instance, pulses of erosion detected in lake sediments can result from both agriculture and climatic activity (Park et al., 2010). In contrast to previous work, this study uses independent proxies that are generally insensitive to anthropogenic influence (i.e. oxygen isotopes) to glean independent evidence of climate change, while charcoal and pollen data provide records of fire activity and vegetation changes. We ask two main research questions. First, what does the Aljojuca record reveal about the character and timing of anthropogenic alteration of the landscape in both pre-historic and the historic period? Secondly, can we distinguish between anthropogenic and climatic influences on the landscape during these two time periods? We also discuss the uncertainty resulting from depositional effects on interpretations of pollen and charcoal data from lake sediments.

\section{Regional Setting and Background}

\section{1 Physical Setting}

Lago Aljojuca $\left(19^{\circ} \mathrm{N}, 97.5^{\circ} \mathrm{W}, 2376\right.$ meters above sea level (masl)) is located in the southern part of the Cuenca Oriental, or Oriental Basin. The Cuenca Oriental is a semi-arid basin located in the rain shadow of the Sierra Madre Oriental, in the eastern Trans-Mexican Volcanic Belt (TMVB) (Fig. 1). The basin is located in the modern Mexican states of Puebla, Tlaxcala, and Veracruz. Aljojuca is approximately $30 \mathrm{~km}$ west of the andesitic composite volcano Orizaba, which reaches a height of 5,636 masl and is Mexico's tallest peak (Robin and Cantagrel, 1982). Aljojuca is one of several maars, or 
explosion craters, that formed during the Pleistocene as a result of phreatomagmatic explosions (Gasca-Duran, 1981). The 30-m deep lake is surrounded by steep walls of basaltic and andesitic volcanic tuffs. A small arroyo, which contains running water only during the summer rainy season, creates a small delta on the eastern side of the lake.

\section{$\underline{2.2 \text { Modern Climate }}$}

The Cuenca Oriental, along with much of central Mexico, has a monsoonal climate and receives the majority of its annual rainfall in the boreal summer, although winter storms provide a small component of total annual rainfall (Douglas et al., 1993). Modern climatological data near Aljojuca reveal that temperature ranges between 6 and $18^{\circ} \mathrm{C}$, while total mean annual precipitation is approximately $800 \mathrm{~mm}$ (Bhattacharya et al., 2015). The summertime distribution of convective activity is bimodal, and features the canícula, or midsummer drought, in July and August (Peralta-Hernández et al., 2008). Interannual variability is strongly correlated with the El Niño-Southern Oscillation and the Atlantic Multidecadal Oscillation, although more research is necessary to clarify the causes of multi-decadal to centennial-scale changes in rainfall in this region (Méndez and Magaña, 2009).

\section{$\underline{2.3 \text { Vegetation and Fire Regimes }}$}

The vegetation of the Cuenca Oriental has been heavily modified by historic land use, and the area around Aljojuca has largely been converted into agricultural fields. Remnant stands suggest that the area surrounding Aljojuca was once covered with open pine-oak woodland with other tree species like juniper (Juniperus deppeana), wild cherry (Prunus serotina), and wild sapote (Casimiroa edulis) prior to agricultural expansion during the historic period (Fernandez, 1985; personal observation, 2013). 
The vegetation of the Cuenca Oriental is largely influenced by elevation, which creates natural gradients of temperature and moisture availability (Figure 1). Near Aljojuca, at elevations of approximately 2,400 masl, vegetation primarily consists of pine-oak woodland, while drier areas at this same elevation feature xeric scrub vegetation that includes oak (Quercus microphylla) and shrubby taxa like beargrass (Nolina parvifolia) and yucca (Yucca spp.) (Klink, 1973; Fernandez, 1985) (Figure 1). The dominant oak species near Aljojuca are $Q$. crassipes, $Q$. crassifolia, $Q$. rugosa, $Q$. microphylla, and $Q$. deserticola (Fernandez Montes, 2009). At the elevation of the lake, the prevalent species of pine is Pinus pseudostrobus var. apulcensis (Fernandez, 1985; Klink, 1973). Juniper (Juniperus deppeana) and yucca (Yucca spp.) are often found bordering agricultural fields and near the bases of hills (Fernandez, 1985). Dry regions of the Cuenca Oriental and the Tehuacan Valley to the south, at elevations slightly below Aljojuca ( 1,500 and 1,900 masl), support deciduous forest often containing by Bursera spp. (Rzedowski, 1978). Higher elevations between 2,700 and 3,000 masl, notably the slopes of Orizaba, are generally covered with pine-oak forest containing $P$. leiophylla, $P$. pseudostrobus, P. tecote, P. montezumae, and Quercus laurina (Fernandez 1985; Fernandez Montes 2009). At elevations exceeding 3,000 masl, the dominant tree is $P$. hartwegii, which grows in monospecific stands with an understory of bunchgrasses including Festuca, Calamagrostis, and Muhlenbergia spp. (Rzedowski, 1978; Lauer and Klaus, 1978; Klink, 1973) (Figure 1). These give way to alpine grasslands at higher elevations (Rzedowski, 1978; Pfeifer, 1966). The presence of pine (P. patula) and fir (Abies religiosa) in moist areas at high elevations may partially result from the moisture supplied by convective clouds that form on mountain slopes (Lauer and Klaus, 1978). 
High elevations may also feature stands of fir (A. religiosa) and alder (Alnus acuminata) along stream courses (Klink, 1973; Conserva and Byrne, 2002).

In addition to elevational gradients, edaphic conditions influence the distribution of plant taxa in the Cuenca Oriental. Areas of the northern Cuenca Oriental with calcareous substrates feature distinctive vegetation. Dry calcareous hills between 2,100 and 2,600 masl support xerophytic taxa including agave (Agave obscura), beargrass (Nolina parvifolia), and yucca (Yucca spp.) (Fernandez, 1985). In some areas, xerophytic taxa may be accompanied by Quercus microphylla and Pinus cembroides, or may include additional xerophytic shrubs like hechtia (Hechtia roseana) and sotol (Dasylirion acrotriche) (Fernandez, 1985). In lower areas, poorly drained, alkali clay soils can give rise to environments with high salinity, favoring taxa tolerant of high salt levels, including the grasses Distichlis spicata and Bouteloua hirsuta (Fernandez, 1985).

Existing research reveals that vegetation in eastern Mexico may be strongly adapted to periodic fire. Two of the pine taxa found near Aljojuca, $P$. hartweggii and $P$. pseudostrobus, have thick, fire-resistant bark, and typically occur in settings with frequent, low-intensity fires (Rodríguez-Trejo and Fulé, 2003). While fires tend to temporarily remove understory vegetation in woodland ecosystems, several oak species occurring near Aljojuca, including Q. deserticola, propagate by resprouting and tend to be more common in fire-prone ecosystems (Rodríguez-Trejo and Myers, 2010; Rodríguez-Trejo, 2008). Other oak species like Q. crassifolia and Q. crassipes are fire resistant and persist in the understory of pine-oak forests in the presence of more frequent fires (Rodríguez-Trejo and Myers, 2010). Studies of chaparral vegetation in the Tehuacan Valley, immediately south of the Cuenca Oriental, suggest that many taxa are fire 
adapted, despite low concentrations of charcoal in the modern soils indicating a paucity of modern fires (Lloret et al., 1999).

In contemporary central Mexico, the sources of fire are largely anthropogenic. Agricultural land use accounts for $50 \%$ of recorded fires, with only $5 \%$ of fires resulting from lightning strikes, and the remaining $45 \%$ resulting from recreational uses, burning of garbage or unknown sources (SEMARNAT, 2002). Natural fires, however, may occur as a result of dry thunderstorms occurring early in the summer rainy season (Lauer and Klaus, 1978). In other regions, climatic variations are known to play an important, indirect role in altering the frequency and severity of fire by changing the flammability of fuel or modifying fuel loads (Westerling et al., 2003; Pausas and Paula, 2012). It is possible that climate has a similar, indirect influence on fire activity in eastern Mexico, despite a paucity of natural ignition sources.

\subsection{Settlement History}

Until recently, little archaeological research had been conducted in the immediate area surrounding Aljojuca. Early $20^{\text {th }}$ century excavations of mounds, known locally as teteles, suggest that the region around the lake was an agricultural area in pre-Columbian times (Linné, 2003). However, these studies predate radiocarbon dating, and many of these features have been lost as a result of recent agricultural land transformation.

Evidence for Formative, or pre-Classic period ( 4,000 - 1,750 cal yr BP), settlement in the Cuenca Oriental is sparse. There is, however, evidence of settlement in adjacent regions. Earliest settlement at Xochitelnango, a site immediately east of the Cuenca Oriental, dates to 2,900 cal yr BP (Castanzo and Sheehy, 2004). This site was in a region later known as the Tepeac domain, located between the Basin of Puebla and the 
Cuenca Oriental. In addition, Cuenca Oriental is near the region where maize is hypothesized to have been first domesticated, the Rio Balsas drainage (Matsuoka et al., 2002; Piperno et al., 2009). Evidence of maize agriculture in Tehuacan Valley to the south of the Cuenca Oriental has been documented as early as 5,490 cal yr BP, and in Tamaulipas in northeastern Mexico by 4,000 cal yr BP (Smith, 2005) (Figure 1). This indicates the widespread diffusion of maize agriculture across eastern Mexico, including the Cuenca Oriental, by the early Formative period. To the south of the Cuenca Oriental in the Tehuacan Valley (Figure 1), evidence of reservoir building at the Purron Dam dates to between 2,650 and 1,700 cal yr BP (Spencer, 2000). However, there is no evidence of pre-Conquest water management practices in the Cuenca Oriental itself (Acuña, 1984). Annual rainfall in the Cuenca Oriental and much of eastern Mexico is marginal for corn agriculture today, suggesting that past agriculture might have been significantly limited by rainfall fluctuations (Heisey and Edmeades, 1999). Armillas (1969) even argued that aridity played an important role in setting the boundary between agricultural societies in southern Mexico and more nomadic societies in the deserts of northern Mexico in pre-Columbian times.

During the Classic period ( 1,750 - 900 cal yr BP), the eastern TMVB was a site of significant pre-Columbian settlement. García-Cook (1976) documented evidence of widespread pre-Columbian settlement across the Cuenca Oriental and adjacent areas. However, the Classic period was a time of population decline and stagnation in the Tepeac region (Anderson et al., 2009). Central Mexico contained several influential urban centers during the Classic period. Cholula, a major pre-Columbian site to the west of the Cuenca Oriental, reached its maximum size between 1,250 and $700 \mathrm{cal}$ yr BP 
(Evans, 2008) (Figure 1). The city of Teotihuacan, which exerted a major cultural influence across much of Mesoamerica, is located in the Valley of Mexico, to the northwest of the Cuenca Oriental (Figure 1). The city declined at approximately 1,400 cal yr BP, possibly as a result of internal revolt (Beramendi-Orosco et al., 2008). Pottery shards stylistically linked to Cholula and Teotihuacan have been found near Aljojuca (Linné, 2003). Another important site is Cantona, $30 \mathrm{~km}$ north of Aljojuca, which rose to prominence in the late Classic period (i.e. approximately between 1,250 and $950 \mathrm{cal}$ yr BP) (García-Cook and Martinez Calleja, 2012) (Figure 1). Archaeologists working at Cantona have suggested that the site obtained agricultural resources from the regions adjacent to Aljojuca, although others have argued that they came instead from the Gulf Coast (Evans, 2008; García-Cook and Martinez Calleja, 2012). The site was occupied between 1,550 and $1,000 \mathrm{cal} \mathrm{yr} \mathrm{BP}$, and at $1250 \mathrm{cal} \mathrm{yr} \mathrm{BP}$ had a population of approximately 90,000 (García-Cook and Merino Carrion, 1998; García-Cook and Martinez Calleja, 2012). Recent research suggests that environmental stress, in the form of volcanic explosions and climatic change, may have played a role in the cultural history of many of these urban centers (Seibe et al., 1996; Plunket and Uruñuela, 2006; Bhattacharya et al., 2015).

During the Post-Classic period (900-429 cal yr BP) periods, the area surrounding Aljojuca was controlled by new regional powers. The Cuenca Oriental was settled by groups like the Olmec-Xicalanca migrating from the east and south, and later by a group that came to be known as the Toltec-Chichimeca, arriving from the northwest (Evans, 2008). The main population and political center of the Chichimec was between the Basin of Puebla and the Cuenca Oriental in the region known as Tepeaca, and was founded 
approximately $683 \mathrm{cal}$ yr BP (Acuña, 1984). Aljojuca is located to the northeast of the Tepeac domain. The Mexica, a powerful indigenous group from the Basin of Mexico, is known to have conquered the Tepeyac region by $484 \mathrm{cal}$ yr BP, and established a tributary state (Acuña, 1984; Gerhard et al., 1986). Post-Conquest written records suggest that Aljojuca was likely a tributary settlement of Quecholac, one of the three largest settlements in the Tepeac domain (Acuña, 1984). Little is known about specific preColumbian land use practices in this region. Early colonial reports refer to indigenous agricultural practices that involved small agricultural plots left fallow during the dry season (Simpson, 1952). While burning practices are not explicitly referenced, modern ethnographic research in central and western Mexico suggests that indigenous people actively used fire to clear plots for agriculture (Casas et al., 1996; Rodríguez-Trejo et al., 2011).

Spanish conquest resulted in major changes in population density and land use in the Cuenca Oriental. Cortes' party crossed the northern edges of the Cuenca Oriental during his first entry into Tenochtitlan (Prescott, 2000). In the first decade after conquest, population decreased dramatically in this region as a result of disease and other factors (Pfeifer, 1966; Gerhard et al., 1986). After the Conquest, the introduction of crops like wheat, and livestock, especially sheep, altered land management practices (Simpson, 1952; Acuña, 1984; Butzer and Butzer, 1995). The Spanish introduced the encomienda system, which in part retained indigenous practices of paying a portion of agricultural produce as tribute to local rulers (Martínez, 1984). In modern times, irrigation has lead to an expansion of agriculture in the Cuenca Oriental, although small subsistence plots 
appear to be the main form of land use immediately around Aljojuca (personal observation, 2013).

\section{Materials and Methods}

\section{$\underline{3.1 \text { Core Recovery and Chronology }}$}

In March 2007, a joint team from the Universidad Nacional Autónoma de México (UNAM) and the German Research Centre for the Geosciences (GFZ) recovered three sediment cores from Aljojuca. The cores were $12 \mathrm{~m}, 6 \mathrm{~m}$, and $8 \mathrm{~m}$ long and were recovered using a Usinger hydraulic piston corer. We developed one composite core from these three separate cores using magnetic susceptibility, high-resolution photographs, and tephra layers. The cores are largely laminated, with occasional turbidites or homogenous sections, and occasional tephra layers (Figure 2). Two tephra layers, at 353 and $551 \mathrm{~cm}$ respectively, contained organic wood fragments, from which we obtained radiocarbon dates.

We developed a core chronology via accelerator mass spectrometer (AMS) radiocarbon dating of wood, twig, and bud fragments at the Lawrence Livermore National Laboratory's Center for Accelerator Mass Spectrometry (LLNL CAMS). For the basal date, we extracted pollen from sediments using acid treatment to remove mineral sediments. We sent this samples to a flow cytometry facility at Indiana University, which can sort out cells with specific morphologies from a bulk sample, to isolate pine pollen grains (Ormerod. 2000; Mensing and Southon, 1999). In total, we obtained 15 radiocarbon dates, although some dates are replicates from the same core depth (Table 1) (Figure 3). 
We explicitly quantified the age uncertainty associated with our age model by using BACON, a Bayesian age modeling program (Blaauw and Christen, 2011). Bayesian age modeling assumes a prior distribution for key parameters used in age modeling, like the sedimentation rate, and uses Markov-Chain Monte Carlo simulations to explicitly model the sediment accumulation history. This allows for the quantification of uncertainty in sediment accumulation rates and the ages associated with each depth in the core. Bayesian methods are also better able to handle scatter across the radiocarbon dates from a core when constructing an age model than traditional regression methods (Blaauw and Christen, 2011).

\subsection{Oxygen Isotopes}

We used stable isotopes of authigenic carbonates to develop an independent proxy of climatic variations. In closed-basin lakes, changes in the ratio of ${ }^{18} \mathrm{O}$ to ${ }^{16} \mathrm{O}$, expressed as $\partial^{18} \mathrm{O}$ reflects changes in the ratio of precipitation to evaporation. $\mathrm{H}_{2}{ }^{16} \mathrm{O}$ tends to evaporate more quickly than $\mathrm{H}_{2}{ }^{18} \mathrm{O}$, while the higher ${ }^{16} \mathrm{O}$ content of atmospheric vapor means that ${ }^{16} \mathrm{O}$ is preferentially returned to the lake in precipitation (Criss et al., 1999). A higher value of $\partial^{18} \mathrm{O}$ indicates a lower ratio of precipitation to evaporation, and a more arid climate (Leng and Marshall, 2002). Because $\partial^{18} \mathrm{O}$ directly records the isotopic composition of lake water, to our knowledge this proxy is not influenced by anthropogenic landscape changes, like erosion. Rosenmeier et al. (2002) showed that in lowland tropical settings, anthropogenic deforestation changes on vapor recycling and soil moisture storage and alters lacustrine isotopic ratios. However, this effect is unlikely to be important in semi-arid ecosystems with sparser vegetation cover than tropical forests. 
We measured stable isotopes of oxygen and carbon on bulk sediment samples, which contain thin laminations of authigenic calcite. To ensure we were only measuring the isotopic signature of authigenic calcite, we visually inspected samples to verify the absence of shells or large grains of calcite. Isotope ratios are reported in $\delta$ notation in \%o relative to Vienna Pee Dee Belemnite (VPDB). Samples were dried at $50^{\circ} \mathrm{C}$ for 24 hours, dissolved in phosphoric acid, and the evolved $\mathrm{CO}_{2}$ gas was measured on an Isoprime Micromass mass spectrometer in the Department of Earth and Planetary Sciences at U.C. Berkeley. Analytical precision is reported relative to the internal laboratory standard derived from limestone, NBS-19 $(n=12)$, and was $\pm 0.037 \%$ for $\delta^{18} \mathrm{O}$ and $\pm 0.027 \%$ for $\delta^{13}$ C. Samples are spaced by approximately 20 years. More details on isotope measurement methods are available in Bhattacharya et al. (2015).

\subsection{Pollen Analysis}

We processed a total of 80 samples of a standard size $\left(1.25 \mathrm{~cm}^{3}\right)$ to extract pollen and microscopic charcoal. We used standard palynological methods, with the additional step of heavy liquid (lithium metatungstate) separation of clay and silt particles from organic matter (Faegri and Iversen, 1989). For our pollen preparations for radiocarbon dating, we refrained from using wooden stir sticks, and acetolysis was omitted to avoid introducing dead carbon into our samples. We added a known number of Lycopodium clavatum spores to each sample to calculate pollen concentrations and accumulation rates (PAR), and counted 300 grains per sample at 400x magnification, analyzing a total of 80 samples.

To ensure that our counts were sufficient to sample the diversity present in pollen spectra, we constructed 'sampling effort' curves for a random selection of pollen levels. 
While counting each slide, we kept track of the total pollen grains counted, and what the count total was each time a new, previously unrecorded, pollen type was seen on the slide. We constructed these curves by counting 10 slides to a total of 500 grains. These curves are analogous to rarefaction analysis in ecology, which is used to assess the adequacy of sampling in biodiverse ecosystems (Gotelli and Colwell, 2001). If no additional new pollen taxa are added as additional pollen grains are counted, we can reasonably conclude that we have adequately sampled the pollen diversity on a given slide. Our results suggested that 300 grain counts were enough to adequately sample the diversity in pollen types, and that the representation of major taxa did not change significantly when we increased counts to 500 grains per level (not shown). We used the University of California Museum of Paleontology pollen reference collection as well as published pollen keys to identify pollen grains (Kapp et al., 2000; Lozano García, 1979). Pollen counts included 108 distinct pollen taxa in our counts, but only taxa present at greater than $1 \%$ in two pollen levels are included in our results. We use the term 'ERA group' to refer to tricolporate, reticulate pollen grains that cannot easily be distinguished. The term comes from an abbreviation for the families Euphorbiaceae, Anacardiaceae, and Rutaceae, which contain many taxa featuring this pollen grain morphology (Horn et al., 1998).

To assess evidence of agriculture, we scanned three additional slides from each level at a magnification of $100 \mathrm{x}$ to look for maize pollen. We suggest that monoporate pollen grains with long axis $\geq 90 \mu \mathrm{m}$ and pore annulus $\geq 12 \mu \mathrm{m}$, represent cultivated maize (Zea mays subsp. mays). We also used Nomarski interference contrast microscopy to eliminate the possibility that these grains represent the grass Tripsacum (Whitehead 
and Langham, 1965). Holst et al., (2007) suggest that it may be difficult to unambiguously identify maize pollen, especially in highland Mexico where the wild progenitor of maize is indigenous. Analyses of modern pollen from cultivated maize and wild teosinte have found significant morphological overlap between these pollen types (Holst et al., 2007). Because of this overlap, it is possible that the maize pollen grains we identify could represent wild teosinte, which is native to the region. However, we chose a relatively conservative size threshold for maize ( $\geq 90 \mu \mathrm{m}$ and pore annulus $\geq 12 \mu \mathrm{m}$ ) in order to reduce this possibility (Whitehead and Langham, 1965). While we acknowledge inherent uncertainty in our maize pollen identifications, the use of a conservative size threshold means that it is likely that pollen meeting these criteria represent domesticated maize. As a result, we refer to these as domesticated maize through the rest of our study. We also scanned core levels coinciding with the historic period, dating to after 429 cal yr BP, for the invasive herb Erodium circutarium. This taxon was probably introduced at the same time as the introduction of sheep to central Mexico, although it subsequently spread in advance of the mission system into Baja California (Mensing and Byrne, 1998; Villaseñor and Espinosa-Garcia, 2004). The oblate, tricolporate pollen type features a distinctive striate-reticulate surface sculpturing that is visible at low magnifications (Mensing and Byrne, 1998). This invasive species serves as an important marker indicating the beginning of the historic period. We used the same slides prepared for maize pollen scans to scan for E. circutarium. All of the raw pollen counts are available in Bhattacharya et al. (2015).

\subsection{Charcoal Analysis}


Both macroscopic and microscopic charcoal are used as proxies of past fire activity (Whitlock and Larsen, 2001). Our analyses focused on microscopic charcoal, which may be transported long distances and provides a regionally integrated signal of fire (Scott and Damblon, 2010). This proxy likely reflects changes in prehistoric fire in the broader Cuenca Oriental, providing a signal that we could compare to the existing regional archaeological record (Scott and Damblon, 2010). In contrast, macroscopic charcoal may primarily reflect local fire immediately around Aljojuca (Whitlock and Larsen, 2001; Scott and Damblon, 2010). Because we were limited by sample material availability given the multi-institutional scope of this project, we were unable to secure sufficient sample volumes from the Aljojuca cores to analyze macroscopic charcoal.

We used high-resolution images and image processing techniques developed in the Quaternary Paleoecology Laboratory at U.C. Berkeley to analyze microscopic charcoal concentrations in pollen residues. A related system was used by Horn et al. (1992) to analyze charcoal concentrations at Lago Catemaco in Veracruz. The system utilized here has been shown to produce reliable counts of charcoal particles on microscope slides in previous studies (Cowart and Byrne, 2013). The system produces high-resolution imagery, with 1 pixel representing a distance of $6.35 \mu \mathrm{m}$. Charcoal particles are identified based on a certain gray-scale threshold and the angularity of particles. An automated system provides a method to quickly scan several slides, and reduces the influence of observer bias on the charcoal data. We scanned 65 levels previously analyzed for pollen, and divided charcoal particles into four size classes of 100-499 $\mu \mathrm{m}^{2}, 500-999 \mu \mathrm{m}^{2}, 1,000-1,999 \mu \mathrm{m}^{2}$, and pieces larger than $2,000 \mu \mathrm{m}^{2}$. Size classes were the same as those used by Horn et al. (1992), and were chosen in order to 
best capture the range of sizes of the particles we observed and to account for the fact that smaller size fractions tend to contain more particles. Different size classes showed similar trends, so we display the accumulation rates of a total of all charcoal particles greater than $100 \mu \mathrm{m}^{2}$ in area. We calculated charcoal concentrations and charcoal accumulation rates (abbreviated CHAR), by quantifying the number of exotic Lycopodium clavatum spores on a slide, and by dividing by the number of years represented by each sample.

Charcoal peaks in sediment cores may result from fire, but may also result from taphonomic effects (i.e. erosional transport of charcoal residing in surface soils into the lake basin). To avoid this problem, we calculated the ratio between charcoal accumulation rates and pollen accumulation rates at each level in the core. Cowart and Byrne (2013) used this technique to explore the importance of various depositional processes on pollen and charcoal accumulation signals in sediment cores. For example, if charcoal and pollen accumulation rates maintain a constant ratio, it suggests that taphonomic effects are important, and both are being deposited via the same depositional processes. This is because the mechanism that produces charcoal (i.e. fire) does not produce pollen, and increased fire activity should register as increased charcoal accumulation rates without necessarily changing pollen accumulation rates (Cowart and Byrne, 2013). We present our charcoal results both as the raw charcoal accumulation rates and as the ratio of charcoal to pollen accumulation rate in Figure 4. Contrasting these two time series provides insight into the influence of taphonomic processes. Raw charcoal data will be made available through submission to the NOAA Paleoclimatology database upon publication.

\section{5 Data Analysis}


A moving average filter was applied to all proxy data in order to emphasize centennial-scale variability, and to make long-term trends in data clearly visible (Shumway and Stoffer, 2011). Both the unsmoothed data and filtered data are shown in the proxy diagrams (Figures 4 and 5). We divided our data into zones by visually inspecting the data to identify major transitions that are robustly visible across multiple proxies.

\section{Results}

\subsection{Chronology}

The 14 radiocarbon dates used to construct the Aljojuca age model feature low measurement error, which is consistently less than $\pm 35{ }^{14} \mathrm{C}$ years (Table 1$)$. However, some of the radiocarbon dates probably represent reworked or pre-aged material. The date at $815 \mathrm{~cm}$ is much older than surrounding dates and represents reworked charcoal (Table 1). We also note a small age reversal between dates at 551 and $612 \mathrm{~cm}$ : the sample at $551 \mathrm{~cm}$ calibrates to $2,132-2,315 \mathrm{cal}$ yr BP, which overlaps with but is slightly older than the date at $612 \mathrm{~cm}$, which calibrates to 1,901-2,108 cal yr BP (Table 1). The $551 \mathrm{~cm}$ date may represent reworked material, or the burnt inner rings of a tree that are older than younger wood from the same tree. This latter possibility is supported by replicate dates obtained from a depth of $383 \mathrm{~cm}$. Two samples of twig and leaf material from $383 \mathrm{~cm}$ calibrate to age ranges of 983-1,225 and 985-1,179 cal yr BP, younger than a charcoal date from the same depth, which calibrates to 1,080-1,274 cal yr BP (Table 1). These results suggest that a certain level of scatter in radiocarbon dates exists simply as a result of depositional effects and the type of material being dated. However, because Bayesian age modeling is able to accommodate a certain level of scatter in radiocarbon dates, we 
included all dates except the date at $815 \mathrm{~cm}$ in the final age model (Blaauw and Christen, 2011).

The Bayesian age model developed using BACON shows that the Aljojuca core spans the last $6,200 \mathrm{cal} \mathrm{yr} \mathrm{BP}$, and features a mean sedimentation rate of $3.5 \mathrm{~mm} / \mathrm{yr}$ (Figure 3). Major changes in the sedimentation rate occur at three points in the core: the sedimentation rate increases from a mean rate of $1.2 \mathrm{~mm} / \mathrm{yr}$ to $5.5 \mathrm{~mm} / \mathrm{yr}$ at approximately $750 \mathrm{~cm}$, decreases to $1.7 \mathrm{~mm} / \mathrm{yr}$ between 550 and $301 \mathrm{~cm}$, and increases increases dramatically to $6.2 \mathrm{~mm} / \mathrm{yr}$ between $301 \mathrm{~cm}$ and the top of the core.

\section{$\underline{4.2 \text { Core Lithology }}$}

The Aljojuca core is dominated by finely alternating light and dark laminations (Figure 2). Qualitative X-ray diffraction suggests that the core lithology is dominated by plagioclase, quartz, secondary clay minerals, and calcite. We suggest that the dark laminations consist of terrigenous materials that are a mix of plagioclase, quartz, and secondary clays eroding from the steep walls surrounding the lake. In contrast, the lightcolored laminations likely represent authigenic calcite that precipitates within the lake. There are several core sections that feature homogenous clays with few laminations (Figure 2). The longer homogenous sections occur at depths of 0-50 cm, 320-420 cm, and 750 and $810 \mathrm{~cm}$ (Figure 2). The core also contains four tephra layers at 353, 551, 880, and 1,041 cm (Figure 2).

\subsection{Changes in Climate, Fire Regimes, and Vegetation}

The Aljojuca core documents major changes in climate, fire, and vegetation in the late Holocene. Figures 4 and 5 display the major changes in the pollen and microscopic 
charcoal data, focusing on the last 4,000 cal yr BP. Note that the ratio of charcoal to pollen accumulation rates is plotted on a logarithmic axis (Figure 4).

\subsubsection{Zone V $(4,000-2700 \mathrm{cal}$ yr BP; 2,050 -750 BCE; $938-805 \mathrm{~cm})$}

There is a slight trend towards more negative $\partial^{18} \mathrm{O}$ values, which decrease from $6.3 \%$ to $-7.23 \%$ in this zone (Figure 4). This zone is also characterized by low pollen accumulation rates that are generally less than 20,000 grains $/ \mathrm{cm}^{2} / y e a r$. Pollen percentages show little change in this zone: Pinus pollen increases from 40 to 50\%, while Quercus pollen remains at approximately $5 \%$ of the total pollen assemblage (Figure 4). Poaceae pollen decreases from 15 to $10 \%$ towards the end of this zone (Figure 5). This zone also features low charcoal accumulation rates that are consistently less than 3000 particles $/ \mathrm{cm}^{2} / y e a r$ (Figure 4). The ratio of charcoal to pollen accumulation rates maintains a constant value of approximately 0.1 (Figure 4).

\subsubsection{Zone IV $(2,700-1,700 \mathrm{cal}$ yr BP; $750 \mathrm{BCE}-250 \mathrm{CE} ; 805-465 \mathrm{~cm})$}

Zone IV begins with depleted $\partial^{18} \mathrm{O}$, averaging $-7.23 \%$, although these values increase towards the end of the zone, ending with an average value of $-5.2 \%$ VPDB at approximately 1,700 cal yr BP In comparison to Zone V, this zone features increased pollen concentrations and charcoal accumulation rates, with average values of 30,402 grains $/ \mathrm{cm}^{2}$ per year and 11,337 particles $/ \mathrm{cm}^{2}$ per year respectively. In addition, the charcoal to pollen accumulation rate increases from 0.1 to 1 .

This zone is characterized by fluctuations in Pinus and Quercus pollen. Between 2700 and 1900 cal yr BP, Pinus increases from $40 \%$ to 60\%, and Quercus increases from approximately $7 \%$ to $10 \%$ (Figure 4). Between 2200 and 1700 cal yr BP, Poaceae, 
Amaranthaceae, high-spine Asteraceae, and low-spine Asteraceae also show an increase (Figure 5). Maize pollen is present at approximately 2,400 cal yr BP (Figure 4).

\subsubsection{Zone III $(1,700-800$ cal yr BP; $250-1150 \mathrm{CE} ; 466-342 \mathrm{~cm})$}

This zone features strongly enriched $\partial^{18} \mathrm{O}$ values, averaging $-2.31 \%$ through the entire section (Figure 4). Charcoal accumulation rates average 45,507 particles/ $\mathrm{cm}^{2} /$ year (Figure 4). Pollen accumulation rates increase in this zone to an average 88,589 grains $/ \mathrm{cm}^{2} /$ year. The charcoal to pollen ratio also increases at the beginning of this zone, with values between 1600 and 1400 cal yr BP that reach 1000, meaning that approximately 1000 charcoal particles are deposited for every pollen grain deposited per $\mathrm{cm}^{2}$ per year (Figure 4).

Changes in pollen percentages through this section show a complex pattern. Pinus stays relatively stable, while Quercus increases to approximately $15 \%$ at approximately 1000 cal yr BP (Figure 4). Both Juniperus-type and Alnus pollen maintain relatively constant percentages averaging $1.4 \%$ and $1.6 \%$ respectively (Figure 4 ). High-spine and low-spine Asteraceae, as well as Poaceae pollen decline at approximately 1,100 cal yr BP (Figure 5). Three maize pollen grains are present at 1,280 cal yr BP (Figure 4).

\subsubsection{Zone II ( 800 - 429 cal yr BP; 1150 -1550 CE; $342-302 \mathrm{~cm})$}

At the beginning of this zone, $\partial^{18} \mathrm{O}$ values show a dramatic shift to values of approximately -8\% (Figure 4). Pinus percentages decline from 80 to 50\%, while Quercus remain relatively stable (Figure 4). Poaceae, high-spine Asteraceae, and Amaranthaceae percentages remain constant in this zone (Figure 5). There was an absence of maize pollen in this zone (Figure 4). 
Both the charcoal accumulation rate and the charcoal to pollen ratio decrease in this zone. Pollen accumulation rates show a declining trend in Zone II, dropping from approximately 84,307 to 6,994 grains/ $/ \mathrm{cm}^{2} /$ year (Figure 4). The charcoal accumulation rate declines in this zone to 22,648 particles $/ \mathrm{cm}^{2} / y$ ear. The charcoal to pollen ratio declines from 1 to 0.1 towards the end of Zone II (Figure 4).

\subsubsection{Zone I ( $430 \mathrm{cal}$ yr BP - present; $1521 \mathrm{CE}$ - present; $302-0 \mathrm{~cm})$}

This zone represents the period after Spanish conquest, which we refer to as the historic or post-Conquest period. $\partial^{18} \mathrm{O}$ shows a trend towards more depleted values, declining from approximately -6 to $-8 \%$ (Figure 4). There is a slight increase in charcoal accumulation rates (Figure 4). However, the charcoal to pollen ratio shows an initial increase and then remains relatively constant at a value of 1 . Pollen that we identify as cultivated maize is present in every level in this zone (Figure 4).

This zone is associated with pronounced changes in pollen percentages. Pinus and Quercus decline, Juniperus-type pollen increases from $2.4 \%$ to nearly 5\% (Figure 4). We also note an increase in ERA group pollen (Figure 4). Poaceae and Amaranthaceae pollen remain relatively constant, and there is an increase in Artemisia from 1.2 to $7.2 \%$ at the end of Zone I (Figure 5). There is a dramatic increase in high-spine Asteraceae, which increases from $8 \%$ to nearly $30 \%$ in Zone I (Figure 5). Unfortunately, we were unable to locate any Erodium circutarium pollen grains in this zone.

\section{Discussion}

We used multiple paleoenvironmental proxies to reconstruct climate, vegetation, and fire activity at Lake Aljojuca. The zones identified in our analysis roughly coincide with the major cultural phases in highland Mexico, and provide a contrasting picture of 
pre- and post- Conquest changes, as well as insights into the interplay of anthropogenic factors and climate on the vegetation and fire history of the site.

\section{$\underline{5.1 \text { Zones V and VI (4,000 cal yr BP- } 1,700 \text { cal yr BP })}$}

The transition from Zone V to Zone VI, at approximately 2,700 cal yr BP, shows some evidence of human activity in the area surrounding Aljojuca. Zone V, from 4,000 and 2,700 cal yr BP, shows a relatively stable, wet climate characterized by depleted oxygen isotope values (Figure 4). Charcoal accumulation rates at this time indicate relatively low fire activity, and pollen percentages indicate little vegetation change during this interval.

In contrast, depleted oxygen isotopes indicate a relatively wet climate in Zone IV. Despite this, there are increases in charcoal accumulation rates and a ten-fold increase in the charcoal to pollen ratio at approximately 1,800 cal yr BP (Figure 4). The increase in the charcoal to pollen ratio suggests that higher charcoal accumulation is due at least in part to increased fire activity instead of depositional effects. In addition, maize pollen is present at approximately 2,400 cal yr BP (Figure 4). This pollen type, coupled with increased fire, suggests an anthropogenic influence on the landscape at this time. However, we do not see a pronounced increase in the pollen of weedy taxa (e.g. Poaceae and Asteraceae), often interpreted as indicators of an open, disturbed landscape, which could indicate anthropogenic landscape clearance (Piperno, 2006) (Figure 5). Therefore, while the presence of maize pollen provides evidence of human activity near Aljojuca, overall evidence of anthropogenic activity is equivocal. However, the timing of the appearance of maize pollen is consistent with regional chronology of human settlement. 
There is growing evidence of Formative period settlement in eastern central Mexico. Ceramics dating from approximately 3,600 cal yr BP have been discovered northwest of the Cuenca Oriental, in central Tlaxcala (Lesure et al., 2006). Sites in the valley of Puebla and the Tehuacan Valley, to the east and south of the Cuenca Oriental respectively, were occupied in the early Formative period (Castanzo and Sheehy, 2004; Lesure et al., 2006). In addition, early settlement at Cantona, in the northern Cuenca Oriental, occurred approximately 2,400 cal yr BP (Garcia-Cook and Merino Carrion, 1998). The end of Zone IV, approximately $1,700 \mathrm{cal}$ yr BP, also coincides with increases in the importance of major urban centers like Teotihuacan and Cholula (Plunket and Urunuela, 2005; Seibe et al., 1996; Manzanilla, 2006; Beramendi Orosco et al., 2009).. The timing of the start of evidence of human activity at Aljojuca is consistent with regional population increases inferred from the broader archaeological record, and this lake site provides new evidence of Formative-period settlement in eastern Central Mexico

\section{$\underline{5.2 \text { Zones III and II }(1,700-430 \mathrm{cal} \text { yr BP) }}$}

Pollen zones III and II, between 1,700 and 430 cal yr BP, contain evidence for anthropogenic activity, as well as evidence of regional climatic changes in eastern Central Mexico. Maize pollen is present in Zone III at approximately 1,300 cal yr BP, and increases in charcoal accumulation rates and the charcoal to pollen ratio indicate elevated fire (Figure 4). Despite this evidence of anthropogenic activity, we note that pollen indicators of disturbance like high-spine Asteraceae decline, which is inconsistent with elevated anthropogenic activity (Figure 5). 
Significant cultural developments occurred during the Classic period in eastern central Mexico. Teotihuacan remained an important regional power in the early Classic, declining at approximately 1,400 cal yr BP (Beramendi Orosco et al., 2009). Cantona was abandoned at approximately $900 \mathrm{cal}$ yr BP (Garcia-Cook and Merino Carrion, 1998). The Terminal Classic period coincided with the resurgence of Cholula, and the rise of sites like Cacaxtla to the northwest of the Cuenca Oriental (Plunket and Uruñuela, 2005; Evans, 2008). Tula, approximately $200 \mathrm{~km}$ to the northwest of the Cuenca Oriental, also rose in the Terminal Classic and early Post-Classic periods, undergoing a period of decline at 750 cal yr BP (Evans, 2008). At Aljojuca, the decline in the charcoal to pollen ratio at approximately $800 \mathrm{cal}$ yr BP may indicate decreased anthropogenic use of fire coinciding with the decline of these major Classic centers and reductions of regional populations.

Zone III also coincides with strongly enriched oxygen isotope values that indicate an arid climate in the Cuenca Oriental and possibly across eastern Central Meixco (Figure 4). Bhattacharya et al. (2015) discussed the implications of this dry interval for cultural developments in the northern Cuenca Oriental, and the history of the city of Cantona. They interpret the signal from this lake record as reflecting a regional climate signal. Here, we focus on the implications of these climate changes for vegetation change in the Aljojuca record.

One of the most notable changes in Zone III is an increase in Quercus pollen (Figure 4). Palynologists working in Central Mexico interpret high Quercus pollen percentages in different ways. Correa-Metrio et al. (2012) suggest that high percentages of Quercus pollen may be characteristic of pine-oak forest despite the overall dominance 
of Pinus and Quercus pollen of the pollen spectra across all vegetation types. Park et al. (2010) interpret a lowered ratio of pine to oak pollen as an indicator of wetter conditions, but this is at odds with the drier climate inferred from oxygen isotope data in Zone III (Figure 4). In other settings, the increased presence of oak pollen has been interpreted as an indicator of temperate, dry conditions associated with an expansion of mid-altitude oak woodland (Almeida-Lenero et al., 2005). The evidence from Aljojuca appears to support this latter interpretation, with the increase in oak pollen possibly indicating an expansion of xeric scrub vegetation, like the desert scrub found at elevations near Aljojuca that contains Q. microphylla and yucca (Fernandez, 1985). Low percentages of weedy taxa, as indicated by high-spine Asteraceae pollen percentages between 1,700 and 800 cal yr BP are difficult to explain, because an expansion in disturbance taxa as a result of climate drying or increased fire might be expected (Figure 5). Rodríguez-Trejo and Myers (2010) note that fire is often key to eliminating understory vegetation and maintaining oak-dominated vegetation. This may have been the case in Zone III, as Increased fire activity eliminated much of the understory herbaceous vegetation around Aljojuca. Or, it is possible that the vegetation in this zone was dominated by xerophytic taxa like beargrass and yucca and contained few members of Poaceae and Asteraceae (Fernandez, 1985).

Climatic drying may have contributed to increased fire activity in Zone III. Agricultural fires are a dominant ignition source in present-day central Mexico (SEMARNAT, 2002). However, climate may play an indirect role in regulating fire frequencies by reducing fuel moisture, or by altering fuel availability (Pausas and Paula, 2012). We suggest that dry conditions in eastern central Mexico resulted in decreased 
fuel moisture, increasing vegetation flammability and the size of the fires that occurred as a result of anthropogenic ignitions, leading to the elevated charcoal to pollen ratio observed in this zone. Yocom et al. (2010) recorded a similar phenomenon in present-day northeastern Mexico, where dry years, often associated with El Niño events, resulted in drier vegetation and more fires. The authors speculate that these fires resulted from a combination of anthropogenic ignition and springtime lightning strikes. It is important to note that our isotope-based record of climate reflects a multidecadally-integrated signal of climate, with each sample reflecting the average climate of an approximately 20 -year period. Dry conditions inferred from our oxygen isotope record could therefore represent periods of more frequent drought. We suggest that these more frequent drought years, combined with anthropogenic ignition sources, resulted in more fires between 1,700 and 800 cal yr BP in Zone III.

Zone II, between 800 and $430 \mathrm{cal}$ yr BP, is characterized by a return to a wetter climate and a decrease in fire activity (Figure 4). The latter is indicated by decreases in the charcoal accumulation rate, although the ratio of charcoal to pollen stays relatively constant (Figure 4). There is a paucity of evidence for human activity in Zone II and an absence of maize pollen (Figure 4). This is surprising, given the fact that historical evidence suggests that Chichimec settlement associated with the Tepeac domain began in the Cuenca Oriental by 683 cal yr BP (Acuña, 1984). In fact, these archaeological reconstructions of late post-Classic settlement in the Tepeac region may underestimate the true size of regional populations (Anderson, 2009). However, the Tepeac domain featured low population densities with isolated, far-dispersed communities (Anderson 2009). This pattern of settlement may have reduced landscape disturbance and could 
account for the lack of evidence of human impact near Aljojuca between 800 and $430 \mathrm{cal}$ yr BP. This settlement pattern may have resulted from the riskiness of intensively cultivating maize in a semi-arid environment with high interannual rainfall fluctuations (Anderson, 2009; Lopez Corral, 2011).

\section{$\underline{5.3 \text { Zone I (430 cal yr BP - present) }}$}

The beginning of Zone I, occurring at approximately 430 cal yr BP, marks the transition to the period of Spanish colonization. Depleted oxygen isotope values suggest climatic conditions in Zone I were wetter than the climate in Zones III or II. Zone I is characterized by increased fire activity, and contains a large peak in charcoal accumulation rates. However, once corrected for depositional processes and plotted as the charcoal to pollen accumulation rate, the increase in charcoal is much more modest and is smaller than the peak in charcoal observed in Zone III (Figure 4). Additional evidence for anthropogenic landscape modification comes from the presence of maize pollen in Zone I (Figure 4).

Several vegetation changes are evident in Zone I. One notable change is an increase in high-spine Asteraceae pollen (Figure 5). In contrast, Amaranthaceae and Poaceae pollen do not show similar increases, although in other studies these taxa have been observed to co-vary with Asteraceae and are generally interpreted as indicators of natural or anthropogenic landscape disturbance (Piperno, 2006). However, Artemisia, which could also indicate landscape disturbance, does increase in Zone I (Figure 5). A decline in arboreal taxa like Pinus and Quercus is consistent with the interpretation of enhanced landscape clearance associated with historic agriculture, although other tree taxa like Juniperus and the ERA group increase in Zone I. 
Observed changes in Zone I may reflect agricultural intensification and invasive species on the landscape during the historic period. The increase in high-spine Asteraceae pollen is curious because it is not correlated with increases in other weedy taxa (i.e. Amaranthaceae and Poaceae). We suggest that this increase might result from the introduction of livestock, especially sheep, by the Spanish. The development of sheep ranching was undoubtedly also responsible for the spread of non-native plant taxa in Mexico. Bernardino de Sahagún, in his Historia General, reports the widespread presence of a non-native herb termed 'quananacaquilitt', which may represent an invasive Asteraceae sow thistle, possibly a Sonchus sp. from the Asteraceae family (Anderson et al., 2012; Villaseñor and Espinosa-Garcia, 2004). However, Sonchus pollen typically has a distinct fenestrate morphology (Kapp et al., 2000), and was not encountered in the Aljojuca samples. It is possible that the Asteraceae pollen increase is the signature of the introduction of a different invasive taxon within this family. Increases in arboreal taxa like Juniperus and the ERA group likely also reflect anthropogenic land uses during the historic period. Today, Juniperus deppeana occurs in the borders of agricultural fields and at the base of hills, and increases in this pollen type may reflect the expansion of agricultural land uses in the Cuenca Oriental (Fernandez, 1985). Increases in Juniperus pollen might also reflect changes in grazing or fire frequencies. The observed increase in ERA group pollen may also result from introduced species in the historic period. Villaseñor and Espinosa-Garcia (2004) note that several species of Euphorbiaceae, Rutaceae, and Anacardiaceae are invasive species in Mexico. In particular, the invasive Peruvian pepper tree (Schinus molle) was introduced to Mexico in 
the late $16^{\text {th }}$ century and now grows in the area around Aljojuca (personal observation, 2013).

Researchers disagree on the relative magnitude of pre- and post-Conquest landscape transformation across central Mexico (Butzer and Butzer, 1997; Heine et al., 2003; Fernandez, 1985; O’Hara et al., 1993). The Aljojuca record suggests that the character of landscape transformation differed between pre-Conquest and historic periods. Maize pollen provides evidence of human occupation in the area around Aljojuca at time intervals from the Formative through the Terminal Classic as well as in the historic period. There is a larger peak in the charcoal to pollen ratio between 1700 and 800 cal yr BP, roughly during the Classic and Terminal Classic periods, than there is in the historic period. This seems to suggest a stronger anthropogenic influence on fire in the pre-Conquest period, although climate drying between 1,700 and 800 cal yr BP may have played a role in increasing fire activity (Figure 4). If anthropogenic uses of fire were higher during the pre-Columbian interval, it contradicts the argument that widespread burning to maintain pasture was responsible for much soil erosion during the Colonial period (Simpson, 1952). However, changes in vegetation associated with the historic period, like the decline in arboreal taxa (Pinus and Quercus), were more dramatic than changes observed in the pre-Conquest period (Figures 4 and 5). These observations from the Aljojuca record suggest that landscape clearance was more extensive following colonization rather than prior to colonization, a conclusion supported by Fernandez' (1985) analysis of historical documents (Figure 4). .

\section{Conclusions}


The Aljojuca core provides important information on anthropogenic landscape transformation in the Cuenca Oriental in both the pre-Columbian and the post-Conquest periods. Increased fire and the presence of maize pollen at 2,700 cal yr BP represent some of the earliest evidence of agriculture settlement in this region of the Cuenca Oriental. This evidence for settlement in the southern Cuenca Oriental is broadly consistent with regional evidence of early Formative period settlement in eastern Mexico (Garcia-Cook, 1976, Spencer, 2000; Castanzo and Sheehy, 2004; Lesure et al., 2006; Evans, 2008). Future geoarchaeological research in this area can provide an important compliment to this work by clarifying the spatial patterns of settlement and agricultural practices used by Formative-era peoples.

The Aljojuca record reveals evidence of anthropogenic activity during the Classic period. Charcoal accumulation rates increased between 1,700 and 800 cal yr BP, possibly as a result of continued agricultural activity during the Classic period. We hypothesize that a drier climate may have played a role in this latter increase, with more frequent drought acting synergistically with anthropogenic ignition sources by increasing vegetation flammability. Additionally, climate drying and increased fire likely resulted in an expansion in the regional extent of xeric scrub vegetation.

Finally, one of the unique features of the Aljojuca record is the dramatic vegetation change associated with the historic period, following Spanish conquest. Some of these changes, like increases in high-spine Asteraceae and ERA group pollen, may be associated with invasive species on the landscape, while declines in Pinus and Quercus pollen may reflect landscape clearance. Increases in Juniperus pollen may reflect agricultural intensification or changes in fire frequency and grazing. 
Uncertainty about the interpretation of paleolimnological data from Aljojuca as an indicator of past anthropogenic activity stems from two main sources. First, uncertainty is associated with our identifications of maize pollen because teosinte, the progenitor of domesticated maize, is native to this area (Holst et al., 2007). Second,taphonomic effects must be considered when interpreting microscopic charcoal data, including charcoal accumulation rates. We correct for this influence by plotting the ratio of charcoal to pollen, which indicates increases in fire during the Classic period and the historic period.

Despite uncertainties, the Aljojuca record is one of the only well-dated late Holocene paleolimnological records from the Cuenca Oriental. In addition, the multiproxy approach used in this study provided independent evidence on climate, fire, and vegetation changes over the past 4,000 years. The Aljojuca record provides new evidence of Formative period human settlement at approximately 2,700 cal yr BP in the Cuenca Oriental. It also provides a contrasting view of landscape change between the pre- and post-Conquest periods, and shows evidence for new invasive species and agricultural intensification during the historic period.

\section{Acknowledgements}

This material is based upon work supported by the National Science Foundation Graduate Research Fellowship under Grant No. DGE 1106400.Additional funding comes from NSF DDRIG (\# BCS-13333370), a U.C. Museum of Paleontology Graduate Research Award (2013-2014, 2014-2015), grants from Berkeley's Stahl Foundation (Summer 2012), UC Berkeley's Larsen Fund, and German Research Foundation (DFG) IODP grant HA 2756/8-1. This article is LLNL-JRNL-657962. We thank Ulrike Kienel (GFZ Potsdam); Harald Boehnel, Kurt Wogau and Gabriela Castañeda (UNAM 
Juriquilla); Christiane Hassel (I.U. Bloomington Center for Flow Cytometry); Tim

Teague and Wenbo Yang (Dept of Earth and Planetary Sciences, U.C. Berkeley); and

several undergraduate assistants. We also thank John Chiang, David Wahl, Liam Reidy, and Cindy Looy for helpful discussions. We thank the editors and two anonymous reviewers for greatly improving this manuscript.

\section{References}

Acuña, R., 1985. Relaciones geográficas del siglo XVI Tlaxcala II. Universidad Nacional Autónoma de México, Instituto de Investigaciones Antropológicas, DF México.

Almeida-Lenero, L., Hooghiemstra, H., Cleef, A.M., van Geel, B., 2005. Holocene climatic and environmental change from pollen records of lakes Zempoala and Quila, central Mexican highlands. Review of Palaeobotany and Palynology 136, 63-92. doi:10.1016/j.revpalbo.2005.05.001

Anderson, J.H., 2009. Prehispanic settlement patterns and agricultural production in Tepeaca, Puebla, Mexico AD 200-1519 (Dissertation). Pennsylvania State University, College Station, PA.

Arnauld, C., Metcalfe, S.E., Petrequin, P., 1997. Holocene climatic change in the Zacapu lake basin, Michoacán: Synthesis of results. Quaternary International 43-44, 173179. doi:10.1016/S1040-6182(97)00033-5

Beramendi-Orosco, L.E., Gonzalez-Hernandez, G., Urrutia-Fucugauchi, J., Manzanilla, L.R., Soler-Arechalde, A.M., Goguitchaishvili, A., Jarboe, N., 2009. Highresolution chronology for the Mesoamerican urban center of Teotihuacan derived from Bayesian statistics of radiocarbon and archaeological data. Quaternary Research 71, 99-107. doi:10.1016/j.yqres.2008.10.003

Bernardino de Sahagun, 2012. Florentine codex: General history of the things of New Spain. University of Utah Press ; School of American Research, Salt Lake City, Utah; Santa Fe, New Mexico.

Bhattacharya, T., Byrne, R., Böhnel, H., Wogau, K., Kienel, U., Ingram, B.L., Zimmerman, S., 2015. Cultural implications of late Holocene climate change in the Cuenca Oriental, Mexico. Proceedings of the National Academy of Sciences 112, 1693-1698. doi:10.1073/pnas.1405653112

Blaauw, M., Christen, J.A., 2011. Flexible Paleoclimate Age-Depth Models Using an Autoregressive Gamma Process. Bayesian Analysis 6, 457-474. doi:10.1214/11BA618

Butzer, K.W., Butzer, E.K., 1997. The "natural" vegetation of the Mexican Bajío: Archival documentation of a 16th-century Savanna environment. Quaternary International 43-44, 161-172. doi:10.1016/S1040-6182(97)00032-3

Butzer, K.W., Butzer, E.K., 1995. Transfer of the Mediterranean Livestock Economy to New Spain: Adaptation and Ecological Consequences, in: Turner II, B.L., Gomez Sal, A., Gonzalez Bernaldez, F., di Castri, F. (Eds.), Global Land Use Change: A Perspective from the Columbian Encounter. Dodecaedro, Madrid. 
Caballero, M., Vilaclara, G., Rodriguez, A., Juarez, D., 2003. Short-term climatic change in lake sediments from lake Alchichica, Oriental, Mexico. Geofisica International 42, 529-537.

Casas, A., Vázquez, M. del C., Viveros, J.L., Caballero, J., 1996. Plant management among the Nahua and the Mixtec in the Balsas River Basin, Mexico: An ethnobotanical approach to the study of plant domestication. Human Ecology 24, 455-478. doi:10.1007/BF02168862

Castanzo, R.A., Sheehy, J.J., 2004. The Formative period civic-ceremonial centre of Xochiltenango in Mexico. Antiquity 78.

Conserva, M.E., Byrne, R., 2002. Late Holocene Vegetation Change in the Sierra Madre Oriental of Central Mexico. Quaternary Research 58, 122-129. doi:10.1006/qres.2002.2348

Cook, A.G., Merino Carrión, B.L., 1998. Cantona: Urbe Prehispanica en el Altiplano Central de Mexico. Latin American Antiquity 9, 191. doi:10.2307/971728

Correa-Metrio, A., Lozano-García, S., Xelhuantzi-López, S., Sosa-Nájera, S., Metcalfe, S.E., 2012. Vegetation in western Central Mexico during the last 50000 years: modern analogs and climate in the Zacapu Basin. Journal of Quaternary Science 27, 509-518. doi:10.1002/jqs.2540

Cowart, A., Byrne, R., 2013. A Paleolimnological Record of Late Holocene Vegetation Change from the Central California Coast. California Archaeology 5, 337-352. doi:10.1179/1947461X13Z.00000000018

Criss, R.E., 1999. Principles of stable isotope distribution. Oxford University Press, New York.

Davies, S.J., Metcalfe, S.E., MacKenzie, A.B., Newton, A.J., Endfield, G.H., Farmer, J.G., 2004. Environmental changes in the Zirahuén Basin, Michoacán, Mexico, during the last 1000 years. Journal of Paleolimnology 31, 77-98. doi:10.1023/B:JOPL.0000013284.21726.3d

Douglas, M.W., Maddox, R.A., Howard, K., Reyes, S., 1993. The Mexican Monsoon. Journal of Climate 6, 1665-1677. doi:10.1175/15200442(1993)006<1665:TMM>2.0.CO;2

Dull, R.A., Nevle, R.J., Woods, W.I., Bird, D.K., Avnery, S., Denevan, W.M., 2010. The Columbian Encounter and the Little Ice Age: Abrupt Land Use Change, Fire, and Greenhouse Forcing. Annals of the Association of American Geographers 100, 755-771. doi:10.1080/00045608.2010.502432

Elliott, M., Fisher, C.T., Nelson, B.A., Molina Garza, R.S., Collins, S.K., Pearsall, D.M., 2010. Climate, agriculture, and cycles of human occupation over the last 4000yr in southern Zacatecas, Mexico. Quaternary Research 74, 26-35. doi:10.1016/j.yqres.2010.04.001

Evans, S.T., 2008. Ancient Mexico \& Central America: archaeology and culture history. Thames \& Hudson, New York.

Faegri, K., Iversen, J., 2000. The textbook of pollen analysis, 4th Edition, Reprint. ed. Blackburn Press, Caldwell, NJ.

Fernández Montes, J.R., 2009. Panorama Historico, Aljojuca.

Fernández, P., 1985. Uso del suelo durante cuatrocientos anos y cambio fisonomico en la zona semiarida Poblano-Veracruzana, Mexico. Biotica 10, 123-144. 
Fisher, C.T., 2005. Demographic and Landscape Change in the Lake Patzcuaro Basin, Mexico: Abandoning the Garden. American Anthropologist 107, 87-95. doi:10.1525/aa.2005.107.1.087

Garcia-Cook, A., 1976. El proyecto arqueologico Puebla-Tlaxcala, in: Proyecto PueblaTlaxcala, Communicaciones, Suplemento: Puebla, Mexico. Fundacion Alemana para la Investigacion Cientifica, pp. 1-60.

Garcia-Cook, A., Martinez Calleja, Y., 2012. Sistemas de almacenamiento en Cantona, Puebla [Storage systems in Cantona, Puebla]., in: Almacenamiento Prehispanico Del Norte de Mexico Al Altiplano Central [Prehispanic Storage from Northern to Central Highland Mexico]. Centro de Estudios Mexicanos y Centroamericanos, Mexico City, pp. 91-107.

Gerhard, P., 1986. Geografía histórica de la Nueva España, 1519-1821. Universidad Nacional Autónoma de México, DF México.

Goman, M., Joyce, A., Mueller, R., Paschyn, L., 2010. Multiproxy paleoecological reconstruction of prehistoric land-use history in the western region of the lower Rio Verde Valley, Oaxaca, Mexico. The Holocene 20, 761-772. doi:10.1177/0959683610362811

Gotelli, N.J., Colwell, R.K., 2001. Quantifying biodiversity: procedures and pitfalls in the measurement and comparison of species richness. Ecology Letters 4, 379-391. doi:10.1046/j.1461-0248.2001.00230.x

Heine, K, 2003. Paleopedological evidence of human-induced environmental change in the Puebla-Tlaxcala area (Mexico) during the last 3500 years. Revista Mexicana de Ciencas Geologicas 20, 235-244.

Heisey, P., Edmeades, G., 1999. 1997/98 World Maize Facts and Trends - Maize Production in Drought Stressed Environments: Technical Options and Research Resource Allocations.International Maize Improvement Center, Mexico City.

Hendrickson, W.A., Ward, K.B., 1975. Atomic models for the polypeptide backbones of myohemerythrin and hemerythrin. Biochem. Biophys. Res. Commun. 66, 13491356.

Holst, I., Moreno, J.E., Piperno, D.R., 2007. Identification of teosinte, maize, and Tripsacum in Mesoamerica by using pollen, starch grains, and phytoliths. Proceedings of the National Academy of Sciences 104, 17608-17613. doi:10.1073/pnas.0708736104

Horn, S.P., Horn, R.D., Byrne, R., 1992. An automated charcoal scanner for paleoecological studies. Palynology 16, 7-12. doi:10.1080/01916122.1992.9989403

Horn, S.P., Rodgers, J.C., Orvis, K.H., Northrop, L.A., 1998. Recent land use and vegetation history from soil pollen analysis: Testing the potential in the lowland humid tropics. Palynology 22, 167-180. doi:10.1080/01916122.1998.9989507

Kapp, R., Davis, O., King, J., 2000. Pollen and Spores. American Association of Stratigraphic Palynologists Foundation Publication, Dallas, USA.

Klink, H.-J., 1973. Natural Vegetation and Its Spatial Distribution in the Puebla-Tlaxcala Area of Mexico. Erdkunde 27, 213-225.

Lauer, W., Klaus, D., 1975. Geoecological Investigations on the Timberline of Pico de Orizaba, Mexico. Arctic and Alpine Research 7, 315. doi:10.2307/1550176 
Leng, M.J., Marshall, J.D., 2004. Palaeoclimate interpretation of stable isotope data from lake sediment archives. Quaternary Science Reviews 23, 811-831. doi:10.1016/j.quascirev.2003.06.012

Leopold, A.S., 1950. Vegetation Zones of Mexico. Ecology 31, 507-518. doi:10.2307/1931569

Lesure, R.G., Borejsza, A., Carballo, J., Frederick, C., Popper, V., Wake, T.A., 2006. Chronology, Subsistence, and the Earliest Formative of Central Tlaxcala, Mexico. Latin American Antiquity 17, 474. doi:10.2307/25063068

Linné, S., 2003. Mexican highland cultures: archaeological researches at Teotihuacan, Calpulalpan, and Chalchicomula in 1934-35. University of Alabama Press, Tuscaloosa.

Liverman, D.M., 1990. Drought Impacts in Mexico: Climate, Agriculture, Technology, and Land Tenure in Sonora and Puebla. Annals of the Association of American Geographers 80, 49-72. doi:10.1111/j.1467-8306.1990.tb00003.x

Lloret, F., Verdu, M., Flores-Hernandez, N., Valiente-Banuet, A., 1999. Fire and resprouting in Mediterranean ecosystems: insights from an external biogeographical region, the Mexican shrubland. American Journal of Botany 86, 1655-1661.

Lopez Corral, A., 2011. Crop subsistence yield variability within Late Postclassic (1325-1521 A.D.) and Early Colonial (16th century) Indigenous communities in the Tepeaca Region, Mexico. The Pennsylvania State University, College Station, PA.

Lozano-García, S., 1979. Atlas de polen de San Luis Potosi, Mexico. Pollen et Spores 21, 287-336.

Manzanilla, L., 2006. Estados corporativos arcaicos. Organizaciones de excepción en escenarios excluyentes. Cuicuilco 13, 13-45.

Martínez, H., 1984. Tepeaca en el siglo XVI: tenencia de la tierra y organización de un señorío, Ediciones de la Casa Chata. Centro de Investigaciones y Estudios Superiores en Antropología Social, México, D.F.

Matsuoka, Y., Vigouroux, Y., Goodman, M.M., Sanchez G., J., Buckler, E., Doebley, J., 2002. A single domestication for maize shown by multilocus microsatellite genotyping. Proceedings of the National Academy of Sciences 99, 6080-6084. doi:10.1073/pnas.052125199

McClung de Tapia, E., 2000. Prehispanic agricultural systems in the basin of Mexico, in: Lentz, D. (Ed.), Imperfect Balance: Landscape Transformations in the PreColumbian Americas, Historical Ecology Series. Columbia University Press, New York, pp. 121-146.

Méndez, M., Magaña, V., 2010. Regional Aspects of Prolonged Meteorological Droughts over Mexico and Central America. Journal of Climate 23, 1175-1188. doi:10.1175/2009JCLI3080.1

Mensing, S., Byrne, R., 1998. Pre-mission invasion of Erodium cicutarium in California. Journal of Biogeography 25, 757-762. doi:10.1046/j.1365-2699.1998.2540757.x

Mensing, S., Southon, J.R., 1999. A simple method to separate pollen for AMS radiocarbon dating and its application to lacustrine and marine sediments 41, 1-8.

Metcalfe, S., Davies, S., 2007. Deciphering recent climate change in central Mexican lake records. Climatic Change 83, 169-186. doi:10.1007/s10584-006-9152-0 
Metcalfe, S.E., Davies, S.J., Braisby, J.D., Leng, M.J., Newton, A.J., Terrett, N.L., O'Hara, S.L., 2007. Long and short-term change in the Pátzcuaro Basin, central Mexico. Palaeogeography, Palaeoclimatology, Palaeoecology 247, 272-295. doi:10.1016/j.palaeo.2006.10.018

O'Hara, S.L., Metcalfe, S.E., Street-Perrott, F.A., 1994. On the arid margin: The relationship between climate, humans and the environment. A review of evidence from the highlands of central Mexico. Chemosphere 29, 965-981. doi:10.1016/0045-6535(94)90163-5

Ormerod, M.G. (Ed.), 2000. Flow cytometry: a practical approach, 3rd ed. ed, The practical approach series. Oxford University Press, Oxford [England]; New York.

Park, J., Byrne, R., Böhnel, H., Garza, R.M., Conserva, M., 2010. Holocene climate change and human impact, central Mexico: a record based on maar lake pollen and sediment chemistry. Quaternary Science Reviews 29, 618-632. doi:10.1016/j.quascirev.2009.10.017

Pausas, J.G., Paula, S., 2012. Fuel shapes the fire-climate relationship: evidence from Mediterranean ecosystems: Fuel shapes the fire-climate relationship. Global Ecology and Biogeography 21, 1074-1082. doi:10.1111/j.14668238.2012.00769.x

Peralta-Hernandez, A.R., Barba-Martinez, L.R., Magana-Rueda, V.O., Matthias, A.D., Luna-Ruiz, J.J., 2008. Temporal and spatial behavior of temperature and precipitation during the canícula (midsummer drought) under El Niño conditions in central México. Atmosfera 21, 265-280.

Pfeifer, G., 1966. The Basin of Puebla-Tlaxcala in Mexico. Revista Geográfica 64, 85107.

Piperno, D.R., 2006. Quaternary environmental history and agricultural impact on vegetation in Central America. Annals of the Missouri Botanical Garden 93, 274 296. doi:10.3417/0026-6493(2006)93[274:QEHAAI]2.0.CO;2

Piperno, D.R., Ranere, A.J., Holst, I., Iriarte, J., Dickau, R., 2009. Starch grain and phytolith evidence for early ninth millennium BP maize from the Central Balsas River Valley, Mexico. Proceedings of the National Academy of Sciences 106, 5019-5024. doi:10.1073/pnas.0812525106

Plunket, P., Uruñuela, G., 2006. Social and cultural consequences of a late Holocene eruption of Popocatépetl in central Mexico. Quaternary International 151, 19-28. doi:10.1016/j.quaint.2006.01.012

Plunket, P., Uruñuela, G., 2005. Recent Research in Puebla Prehistory. Journal of Archaeological Research 13, 89-127. doi:10.1007/s10804-005-2485-5

Prescott, W.H., 2000. History of the conquest of Mexico ; \& History of the conquest of Peru, 1st Cooper Square Press ed. ed. Cooper Square Press, New York.

Robin, C., Cantagrel, J.M., 1982. Le Pico de Orizaba (Mexique): Structure et evolution d'un grand volcan andesitique complexe. Bulletin Volcanologique 45, 299-315. doi:10.1007/BF02597254

Rodriguez-Trejo, D.A., 2008. Fire Regimes, Fire Ecology, and Fire Management in Mexico. AMBIO: A Journal of the Human Environment 37, 548-556. doi:10.1579/0044-7447-37.7.548 
Rodríguez-Trejo, D.A., Fulé, P.Z., 2003. Fire ecology of Mexican pines and a fire management proposal. International Journal of Wildland Fire 12, 23. doi:10.1071/WF02040

Rodríguez-Trejo, D.A., Martínez-Hernández, P.A., Ortiz-Contla, H., Chavarría-Sánchez, M.R., Hernández-Santiago, F., 2011. The Present Status of Fire Ecology, Traditional Use of Fire, and Fire Management in Mexico and Central America. Fire Ecology 7, 40-56. doi:10.4996/fireecology.0701040

Rodriguez-Trejo, D.A., Myers, R.L., 2010. Using Oak Characteristics to Guide Fire Regime Restoration in Mexican Pine-Oak and Oak Forests. Ecological Restoration 28, 304-323. doi:10.3368/er.28.3.304

Rosenmeier, M.F., Hodell, D.A., Brenner, M., Curtis, J.H., Martin, J.B., Anselmetti, F.S., Ariztegui, D., Guilderson, T.P., 2002. Influence of vegetation change on watershed hydrology: implications for paleoclimatic interpretation of lacustrine $\delta 180$ records. Journal of Paleolimnology 27, 117-131.

Scott, A.C., Damblon, F., 2010. Charcoal: Taphonomy and significance in geology, botany and archaeology. Palaeogeography, Palaeoclimatology, Palaeoecology 291, 1-10. doi:10.1016/j.palaeo.2010.03.044

SEMARNAT, 2002. Incendios forestales.

Shumway, R.H., Stoffer, D.S., 2011. Time series analysis and its applications: with R examples, 3rd ed. ed, Springer texts in statistics. Springer, New York.

Siebe, C., Abrams, M., Luis Macías, J., Obenholzner, J., 1996. Repeated volcanic disasters in Prehispanic time at Popocatépetl, central Mexico: Past key to the future? Geology 24, 399. doi:10.1130/00917613(1996)024<0399:RVDIPT>2.3.CO;2

Simpson, L.B., 1952. Exploitation of Land in Central Mexico in the Sixteenth Century, Ibero-Americana. University of California Press, Berkeley.

Smith, B.D., 2005. Reassessing Coxcatlan Cave and the early history of domesticated plants in Mesoamerica. Proceedings of the National Academy of Sciences 102, 9438-9445. doi:10.1073/pnas.0502847102

Spencer, C.S., 2000. Prehispanic water management and agricultural intensification in Mexico and Venezuela, in: Lentz, D. (Ed.), Imperfect Balance: Landscape Transformations in the Pre-Columbian Americas, Historical Ecology Series. Columbia University Press, New York, pp. 147-178.

Straka, H., Ohngemach, D., 1989. Late Quaternary vegetation history of the Mexican highland. Plant Systematics and Evolution 162, 115-132.

Vazquez, G, Ortega B, Davies, S.J., Aston, B.J., 2010. Registro sedimentario de los últimos ca. 17000 años del lago de Zirahuén, Michoacán, México. Boletín de la Sociedad Geológica Mexicana 62, 325-343.

Villaseñor, J.L., J. Espinosa-Garcia, F., 2004. The alien flowering plants of Mexico: Alien plants of Mexico. Diversity and Distributions 10, 113-123. doi:10.1111/j.1366-9516.2004.00059.x

Wahl, D., Estrada-Belli, F., Anderson, L., 2013. A 3400 year paleolimnological record of prehispanic human-environment interactions in the Holmul region of the southern Maya lowlands. Palaeogeography, Palaeoclimatology, Palaeoecology 379-380, 17-31. doi:10.1016/j.palaeo.2013.03.006 
Walsh, M.K., Prufer, K.M., Culleton, B.J., Kennett, D.J., 2014. A late Holocene paleoenvironmental reconstruction from Agua Caliente, southern Belize, linked to regional climate variability and cultural change at the Maya polity of Uxbenká. Quaternary Research 82, 38-50. doi:10.1016/j.yqres.2014.01.013

Westerling, A.L., Gershunov, A., Brown, T.J., Cayan, D.R., Dettinger, M.D., 2003. Climate and Wildfire in the Western United States. Bulletin of the American Meteorological Society 84, 595-604. doi:10.1175/BAMS-84-5-595

Whitehead, D.R., Langham, E.J., 1965. Measurement as a Means of Identifying Fossil Maize Pollen. Bulletin of the Torrey Botanical Club 92, 7. doi:10.2307/2483309

Whitlock, C., Larsen, C., 2002. Charcoal as a Fire Proxy, in: Smol, J.P., Birks, H.J.B., Last, W.M., Bradley, R.S., Alverson, K. (Eds.), Tracking Environmental Change Using Lake Sediments. Kluwer Academic Publishers, Dordrecht, pp. 75-97. Yocom, L.L., Fulé, P.Z., Brown, P.M., Cerano, J., Villanueva-Díaz, J., Falk, D.A., Cornejo-Oviedo, E., 2010. El Niño-Southern Oscillation effect on a fire regime in northeastern Mexico has changed over time. Ecology 91, 1660-1671. doi:10.1890/09-0845.1

\section{Figure Captions}

Figure 1. a) Map of highland Mexico. For reference a blue dot indicates Aljojuca, and black dots indicate major cultural centers. Inset map shows the location of the map within the broader context of Central America. Regional map modified with permission from Bhattacharya et al. (2015). b) Topography dashed box in main panel of a, data available from the U.S. Geological Survey. Contours from 2200-6000 masl are plotted at $200 \mathrm{~m}$ intervals c) Cartoon schematic of vegetation zonation moving from Aljojuca up the slopes of Orizaba, inferred and modified from Klink (1973). Topography is exaggerated to illustrate changes. The horizontal length of the profile is approximately $30 \mathrm{~km}$.

Figure 2. Core stratigraphy, showing location of dates, with 2-sigma calibrated age ranges. Locations of laminated sections, homogenous sections, and tephra layers are also indicated. Modified with permission from Bhattacharya et al. (2015).

Figure 3. Sediment core chronology created using Bayesian age modeling package, Bacon (Blaauw and Christen, 2011). Dashed lines provide 95\% confidence intervals of dates for a given depth. Grayscale intensity shows likelihood of an age for a given depth. See text for more details. Modified with permission from Bhattacharya et al. (2015).

Figure 4. Summary diagram showing the representation of arboreal taxa, agricultural indicators (Zea mays subsp. mays), charcoal accumulation rates, pollen concentration, and independent climate data inferred from $\partial^{18} \mathrm{O}$. Labels on oxygen isotope plot indicate the side of the axis that shows wet and dry conditions. Note scale changes. CHAR refers to charcoal accumulation rate, while PAR refers to pollen accumulation rate. CHAR/PAR ratio is plotted on a logarithmic scale.

Figure 5. Summary diagram showing data for herbaceous taxa. Only taxa present at $>1 \%$ in two or more samples are included. Note scale changes. See text for more details. 
Figure 1
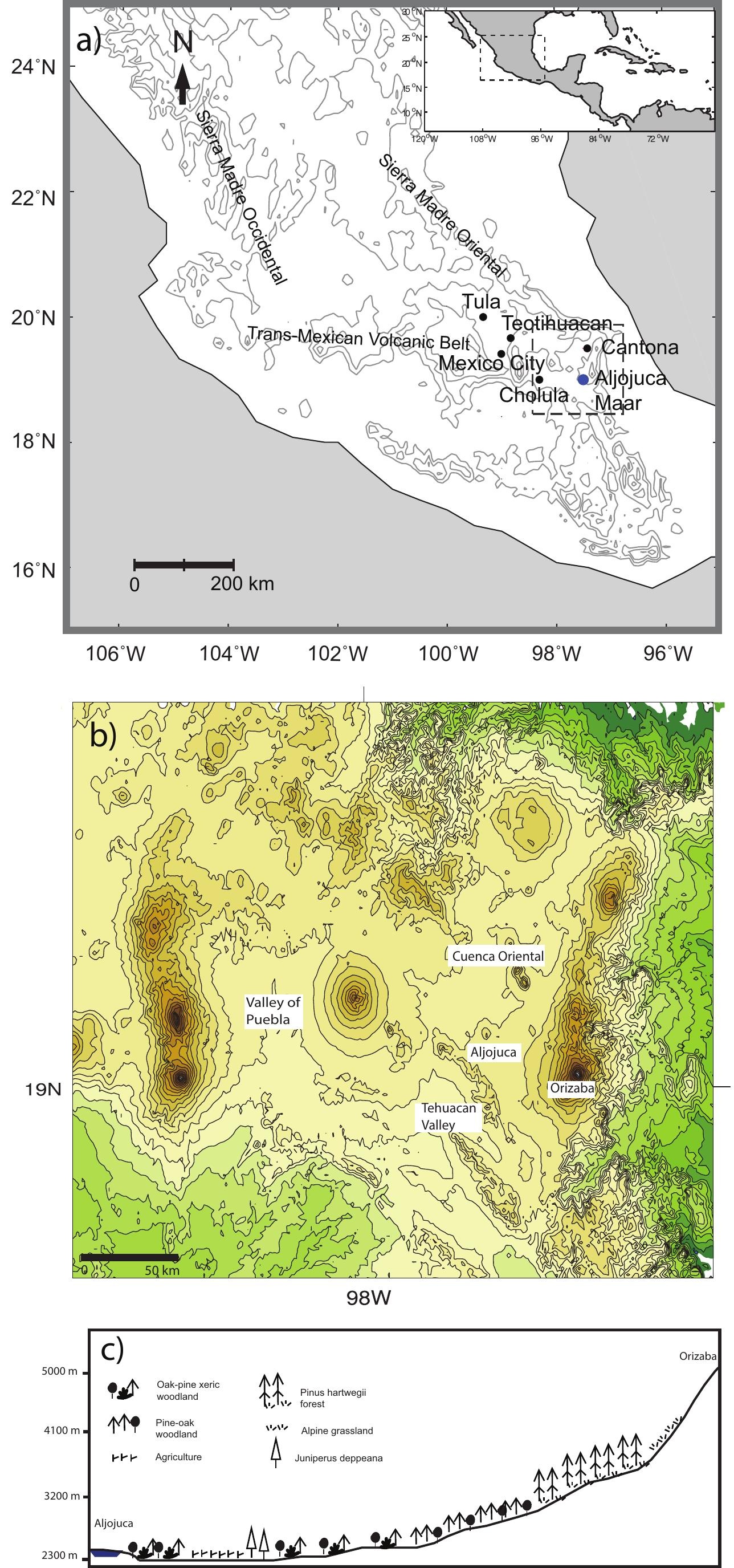
Laminated

.- -. Tephra

Homogenous Clay

Homogenous Clay with

Intermittent Laminae

AMS 14-C Date

口
1263-1340

985-1179

983-1225

1080-1274

1308-1506

1407-1555

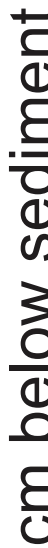

2132-2315

1901-2108

600

400

300

$-$
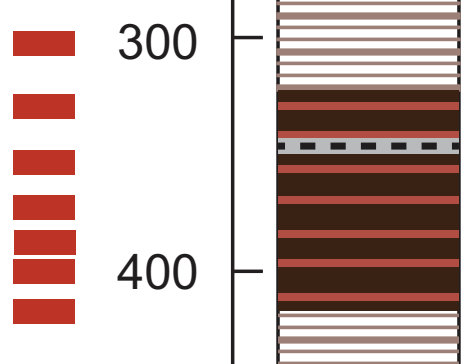

모드.

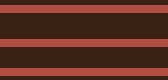

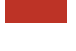

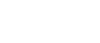

-

500
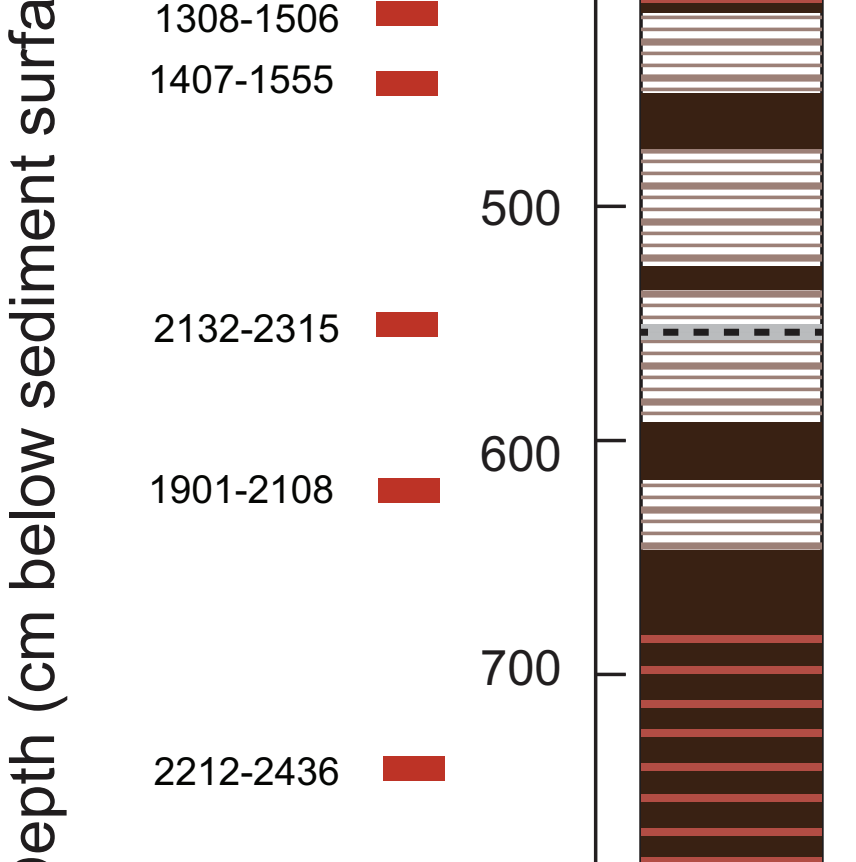

35966-36637

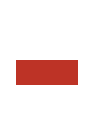

800

2000

(1)

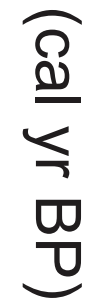

3000

4000

5000

1100

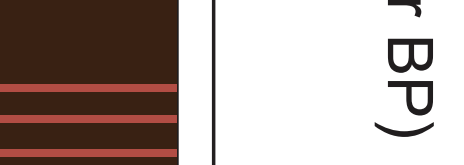

1000

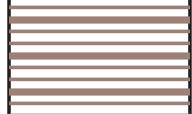




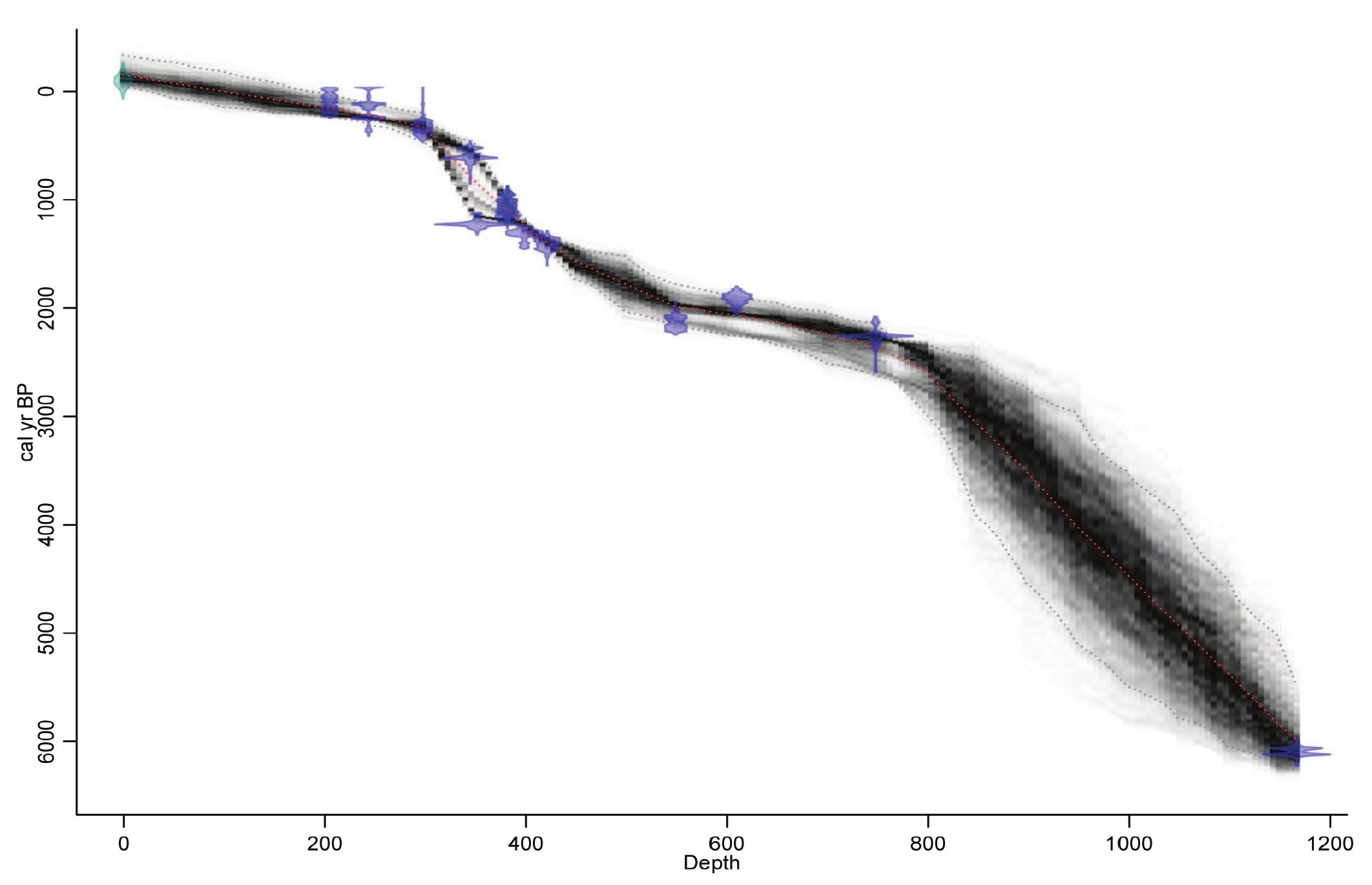

\begin{tabular}{lllrrrr}
\hline 1 & 1 & 1 & 1 & 1 & 1 \\
0 & 200 & 400 & Depth & 800 & 1000 & 1200
\end{tabular}

Figure 3

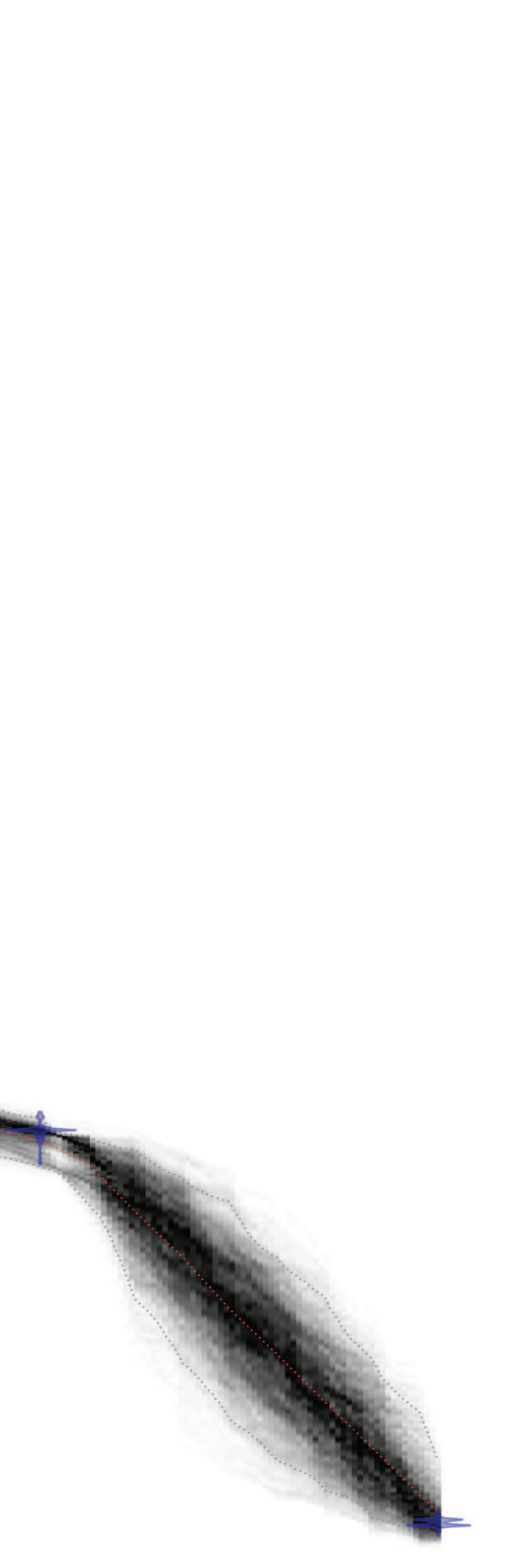




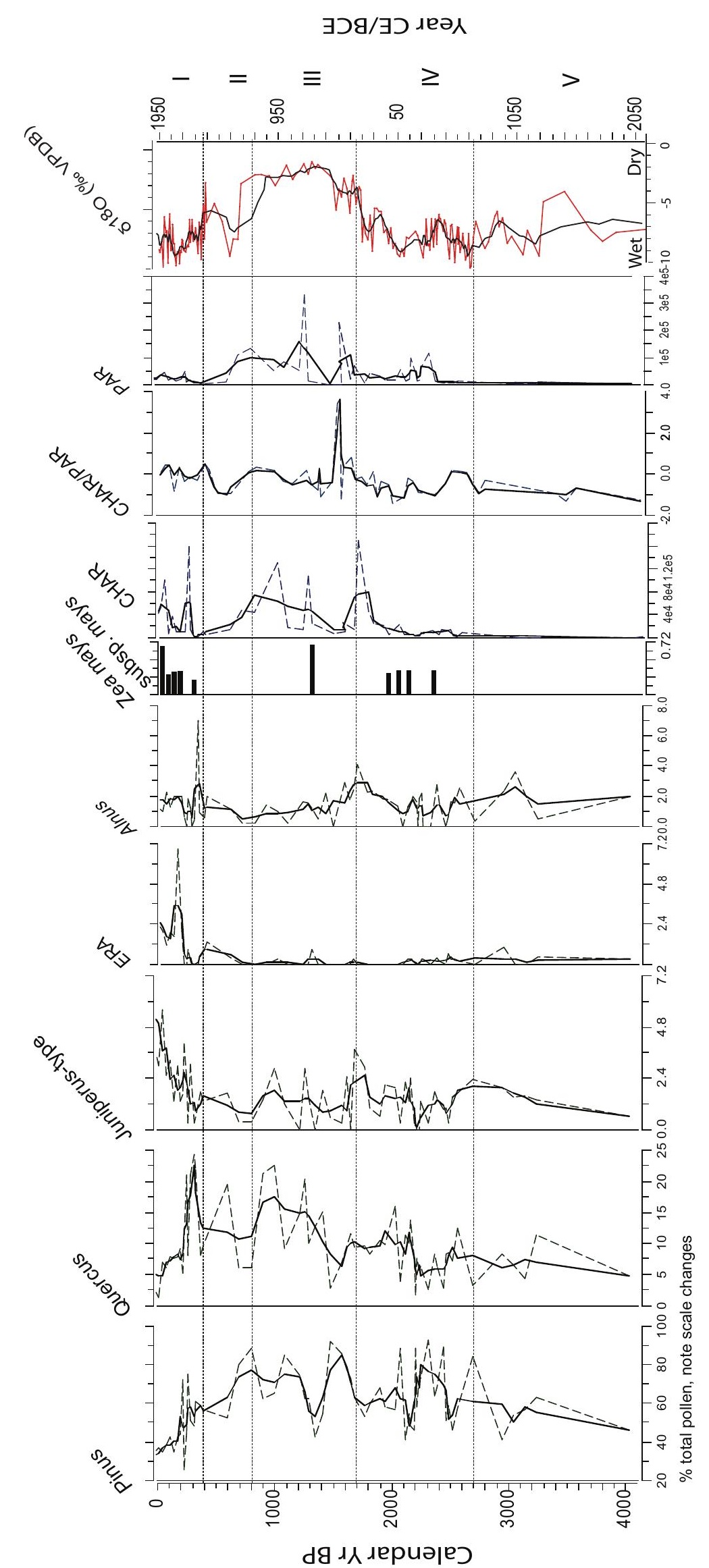

Figure 4 
Figure 5

ヨつタ/ヨつ леәᄉ

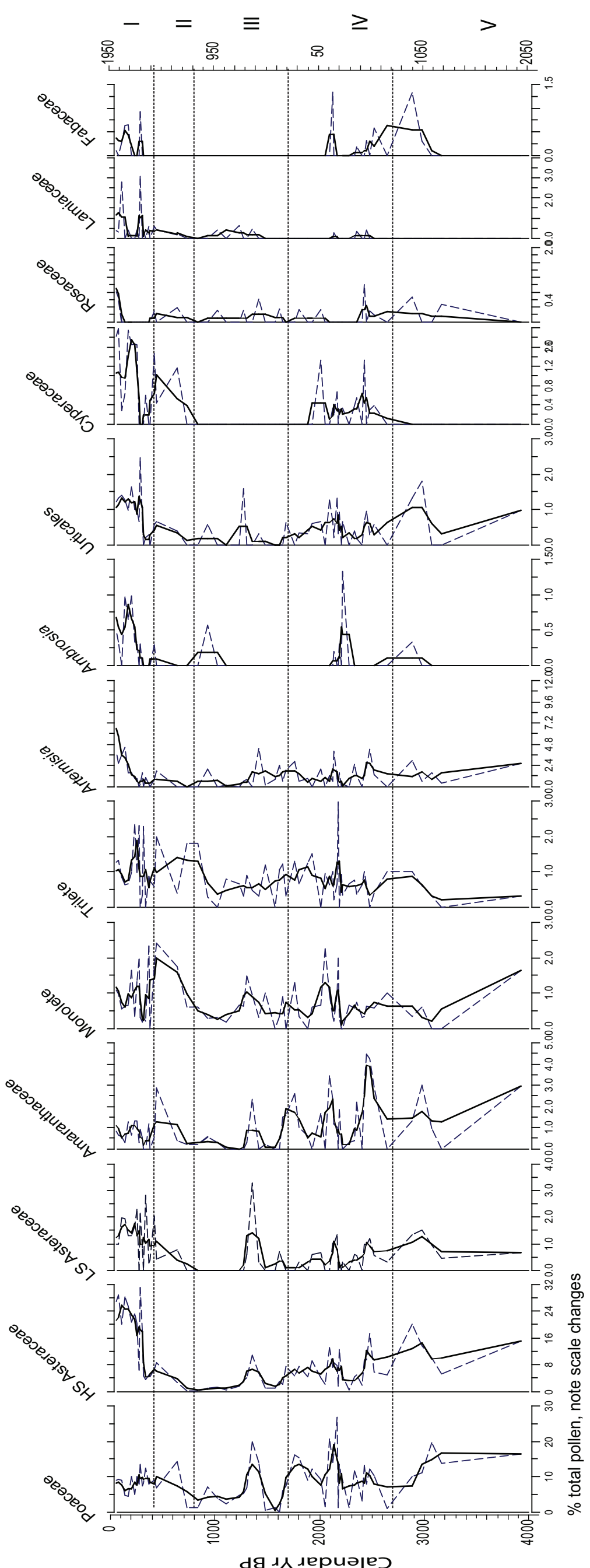


Table 1. Radiocarbon dates obtained from Aljojuca Core. * indicates a reversed date that is thousands of years older than any other date and was not included in the age model

\begin{tabular}{|c|c|c|c|c|c|}
\hline Lab Code & Depth (cm) & Material & $\begin{array}{l}\text { 14C } \\
\text { Age }\end{array}$ & Error & $2 \sigma$ cal. age range BP \\
\hline CAMS150476 & 206 & Wood fragment & 140 & 35 & $5-281$ \\
\hline CAMS166538 & 245 & $\begin{array}{l}\text { Bud, twig } \\
\text { Likely } \\
\text { Juniperus }\end{array}$ & 225 & 35 & $0-422$ \\
\hline CAMS168422 & 304 & Wood fragment & 330 & 30 & $307-473$ \\
\hline CAMS168423 & 342 & Wood fragment & 705 & 30 & $561-691$ \\
\hline CAMS163698 & 353 & Charcoal & 1370 & 30 & $1263-1340$ \\
\hline CAMS168424 & 383 & Charcoal & 1250 & 30 & $1080-1274$ \\
\hline CAMS168426 & 383 & $\begin{array}{r}\text { Possible Pinus } \\
\text { scales }\end{array}$ & 1180 & 35 & $983-1225$ \\
\hline CAMS168425 & 383 & Wood fragment & 1170 & 30 & $985-1179$ \\
\hline CAMS155155 & 400 & Wood fragment & 1495 & 30 & $1308-1506$ \\
\hline CAMS150477 & 423 & Wood fragment & 1600 & 35 & $1407-1555$ \\
\hline CAMS163697 & 551 & $\begin{array}{l}\text { Charcoal } \\
\text { fragments }\end{array}$ & 2195 & 30 & $2132-2315$ \\
\hline CAMS150478 & 612 & $\begin{array}{r}\text { Wood, possibly } \\
\text { Pinus }\end{array}$ & 2035 & 30 & $1901-2108$ \\
\hline CAMS166539 & 750 & $\begin{array}{r}\text { Monocot } \\
\text { fragment, burnt }\end{array}$ & 2330 & 30 & $2212-2436$ \\
\hline CAMS155154 & 815 & $\begin{array}{r}\text { Flower or leaf } \\
\text { fragment }\end{array}$ & 32420 & 210 & $35966-36637^{*}$ \\
\hline CAMS155795 & 1170 & $\begin{array}{r}\text { Pine pollen } \\
\text { concentration }\end{array}$ & 5460 & 25 & $6210-6302$ \\
\hline
\end{tabular}

